IJPSR (2011), Vol. 2, Issue 2

(Research Article)
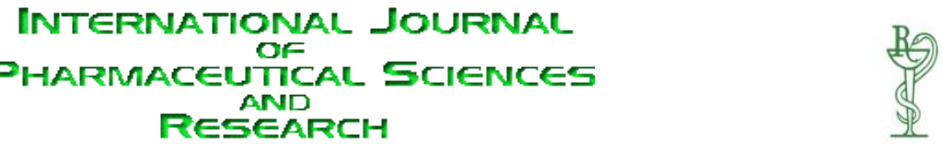

Received on 12 September, 2010; received in revised form 12 December, 2010; accepted 17 January, 2011

\title{
DEVELOPMENT AND VALIDATION OF SPECTROPHOTOMETRIC METHOD FOR THE DETERMINATION OF RISPERIDONE IN BULK DRUG AND PHARMACEUTICAL FORMULATION
}

Moynul Hasan ${ }^{1}{ }^{1}$, Abdullh Al Masud ${ }^{2}$ and Jamiuddin Ahmed $^{3}$

Department of Pharmacy, Dhaka International University ${ }^{1}$, Banani, Dhaka, Bangladesh

ACl Pharmaceuticals Ltd. ${ }^{2}$, Dhaka, Bangladesh

Department of pharmacy, Primeasia University ${ }^{3}$, Banani, Dhaka, Bangladesh

Keywords:

Risperidone,

Spectroscopy,

Estimation,

Validation

Correspondence to Author:

Moynul Hasan

Department of Pharmacy, Dhaka International University, Banani, Dhaka, Bangladesh

\begin{abstract}
A simple, sensitive and accurate spectrophotometric method has been developed for the deterrmination of Risperidone in raw material and capsule. The $\lambda_{\max }$ of Risperidone was found to be $202 \mathrm{~nm}$. Risperidone obeys linearity within the concentration range of 2.5 to $20 \mu \mathrm{g} / \mathrm{mL}$ and coefficient correlation was found to be 0.9991.The regression of the curve was $Y=$ $0.0508 \mathrm{X}+0.0112$. The $\% \mathrm{RSD}$ value is below 2.0 for intraday and interday precision indicated that the method is highly precised. The percentage recovery value was higher than $100 \%$, indicating the accuracy of the method and absence of interference of the excipients present in the formulation. The proposed method will be suitable for the analysis of Risperidone in bulk and pharmaceutical formulations.
\end{abstract}


INTRODUCTION: Risperidone is psychotropic agent used to treat schizophrenia, action of which is mediated through a combination of dopamine Type $2\left(\mathrm{D}_{2}\right)$ and serotonin Type $2\left(5 \mathrm{HT}_{2}\right)$ receptor antagonism. It is a selective monoaminergic antagonist with high affinity for $5 \mathrm{HT}_{2}, \mathrm{D}_{2}$ and $\mathrm{H} 1$ histaminergic receptors ${ }^{1}$. It belongs to chemical class of benzisoxazole derivatives and is 3-[2-[4-(6fluoro-1, 2-benzisoxazol-3-yl)-1-piperidinyl] ethyl]$6,7,8$, 9-tetrahydro-2-methyl-4H-pyrido- [1, 2-a]pyrimidin-4-one (Fig. 1) with molecular formula of $\mathrm{C}_{23} \mathrm{H}_{27} \mathrm{FN}_{4} \mathrm{O}_{2}$ and molecular weight of 410.49 .

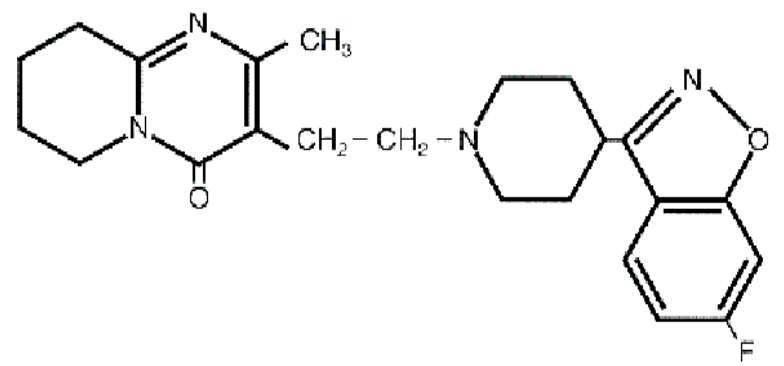

FIGURE 1: STRUCTURE OF RISPERIDONE

Literature survey revealed that various methods have been reported for estimation of Risperidone in biological matrices such as plasma with help of $\mathrm{LC}^{2,3}$, LC with diode array detection ${ }^{4}$, LC with tandem mass spectrometry ${ }^{5,6,7}$ and LC with electrochemical detection ${ }^{8}$. Few stabilityindicating methods have been reported for determination of Risperidone in bulk powder and tablets in presence of its degradation products ${ }^{9,10}$.

However very few methods were reported for quantitation of Risperidone in tablet dosage forms in the literature. The objective of the present investigations was to develop a simple, accurate and economical spectrophotometric methods for estimation of Risperidone in tablet formulations.

\section{MATERIALS AND METHODS:}

Chemicals and Reagents: Risperidone was receieved as a gift sample from $\mathrm{ACl}$ Pharmaceutical Ltd, Bangladesh and Risperidone tablet manufactured by Orion Laboratories Ltd,
Bangladesh were purchased from local market. Analytical grade Hydrochloric acid (0.1N HCL) used as solvent.

Instruments: UV-Visible double beam spectrophotometer (UV-1601 PC SHIMADZU Limited, Japan), Micropipette of Variable volume 10-1000 $\mu \mathrm{L}$ (Gene Pete Co.) and Digital balance (Citizen Co.)

\section{Methods:}

Selection of Wavelength: In order to ascertain the wavelength of maximum absorption $\left(\lambda_{\max }\right)$ of the drug, different solutions of the drugs $(5 \mu \mathrm{g} / \mathrm{mL}$ and $10 \mu \mathrm{g} / \mathrm{mL}$ ) in $0.1 \mathrm{~N} \mathrm{HCl}$ were scanned using spectrophotometer within the wavelength region of $200-380 \mathrm{~nm}$ against methanol as blank. The resulting spectra showed characteristic absorption maxima at $202 \mathrm{~nm}$ for Risperidone.

\section{Preparation of Standard Solution for Calibration:} $10 \mathrm{mg}$ Standard Risperidone was accurately weighed and transferred to $100 \mathrm{~mL}$ volumetric flask and was dissolved properly and diluted up to the mark with $0.1 \mathrm{~N} \mathrm{HCl}$. Then $5 \mathrm{~mL}$ of this solution was diluted to $100 \mathrm{~mL}$ with $0.1 \mathrm{~N} \mathrm{HCl}$. Appropriate amounts of this stock solution were diluted with the same solvent, yields concentrations of $2.5 \mu \mathrm{g} / \mathrm{mL}, \quad 5 \mu \mathrm{g} / \mathrm{mL}, \quad 10 \mu \mathrm{g} / \mathrm{mL}, 15 \mu \mathrm{g} / \mathrm{ml}$ and $20 \mu \mathrm{g} / \mathrm{mL}$ which were used for the construction of calibration curve.

Preparation of Sample Solution: Twenty tablets were weighed accurately and powdered. Powder equivalent to $10 \mathrm{mg}$ of Risperidone was weighed and transferred to a $100 \mathrm{ml}$ volumetric flask. About $40 \mathrm{~mL}$ of $0.1 \mathrm{~N} \mathrm{HCl}$ was added and sonicated for 5 min for complete dissolution of drugs, the volume was made upto the mark with the same solvent and then the above solution was filtered through whatman filter paper. Now $5 \mathrm{~mL}$ of the filtrate is transferred to a $100 \mathrm{~mL}$ volumetric flask and then the volume was made upto the mark with the same 
solvent. After suitable dilution, the absorbance of final sample was recorded against the blank at 202 $\mathrm{nm}$. All determinations were conducted in triplicate (Table 1).

The proposed method was validated according to ich guidelines for linearity, precision, accuracy, stability, lod, loq and stability ${ }^{11}$ (Table 2 ).

Linearity: The linearity of this method was determined at five concentration levels ranging from $2.5 \mu \mathrm{g} / \mathrm{mL}-20 \mu \mathrm{g} / \mathrm{mL}$. The plot of absorbance Vs respective concentration (Fig. 2) of Risperidone was found to be linear in the range of $2.5 \mu \mathrm{g} / \mathrm{mL}$ $20 \mu \mathrm{g} / \mathrm{mL}$. Beer's law was obeyed over this concentration range. The regression equation was found to be $Y=0.0508 \mathrm{X}+0.0112$ and the correlation coefficient $(r)$ of the standard curve was found to be 0.9991 (Table 2).

Precision: The precision of the assay was determined by repeatability (intraday) and intermediate precision (inter-day) and reported as $\%$ RSD. For this, $5 \mu \mathrm{g} / \mathrm{mL}$ concentration solution was measured three times in day and same was measured in next three days. Then the \%RSD was calculated.

Accuracy (Recovery Studies): Recovery studies were performed to judge the accuracy of the method and were carried out by adding a known quantity of pure drug to the preanalyzed formulation and the proposed method was followed. From the amount of drug found, percentage recovery was calculated. Recovery study was carried out at three levels $80 \%, 100 \%$ and $120 \%$ for the formulation concentration of $5 \mu \mathrm{g} / \mathrm{mL}$ (Table 3).

LOD \& LOQ: LOD $(k=3.3)$ and LOQ $(k=10)$ of the method were established according to $\mathrm{ICH}$ definitions. LOD and LOQ of method are reported in Table 2. In this study, LOD and LOQ were based on the standard deviation of the response and the slope of the corresponding curve using the following equations;

$$
L O D=3.3 \mathrm{~S} / \mathrm{M} ; \mathrm{LOQ}=10 \mathrm{~S} / \mathrm{M}
$$

Where $S$ is the standard deviation of the absorbance of the sample and $M$ is the slope of the calibrations curve.

Stability Study: In order to demonstrate the stability of both standard and sample solutions during analysis, both solutions were analyzed over a period of $24 \mathrm{~h}$ at room temperature and \% RSD of absorbance for both solutions was calculated.

RESULTS \& DISCUSSION: The $\lambda_{\max }$ of Risperidone was found to be $202 \mathrm{~nm}$. From the optical characteristics (Table 2) of the proposed method, it was found that Risperidone obeys linearity within the concentration range of 2.5 to $20 \mu \mathrm{g} / \mathrm{mL}$ and coefficient correlation was found to be 0.9991 . The regression of the curve was $Y=0.0508 X+0.0112$. The detection and quantization limits as LOD $(k=3.3)$ and LOQ $(k=10)$ were calculated and these were found to be $1.05 \mu \mathrm{g} / \mathrm{mL}$ and $3.34 \mu \mathrm{g} / \mathrm{mL}$ respectively.

The precision (measurements of intraday and interday) results showed (Table 2) good reproducibility with percent relative standard deviation (\% RSD) is below 2.0. This indicated that method is highly precised. The percentage recovery value (table 3), which was higher than $100 \%$, indicating the accuracy of the method and absence of interference of the excipients present in the formulation.

The results of stability study showed that for both solutions, the absorbance remained almost similar (\% R.S.D. less than 2.0) and no significant degradation within the indicated period, thus indicated that both solutions were stable for at least $24 \mathrm{~h}$, which was sufficient to complete the whole analytical process. The proposed method 
was also applied for the assay of Risperidone in tablet formulation (in triplicate) and the results are presented in Table 4. The results obtained were good agreement with the label claims.

\section{TABLE 1: DATA FOR STANDARD CURVE}

\begin{tabular}{cc}
\hline Concentration $(\mu \mathrm{g} / \mathrm{ml})$ & Absorbance \\
\hline 0.00 & 0.000 \\
2.5 & 0.134 \\
5 & 0.278 \\
10 & 0.525 \\
15 & 0.785 \\
20 & 1.014 \\
\hline
\end{tabular}

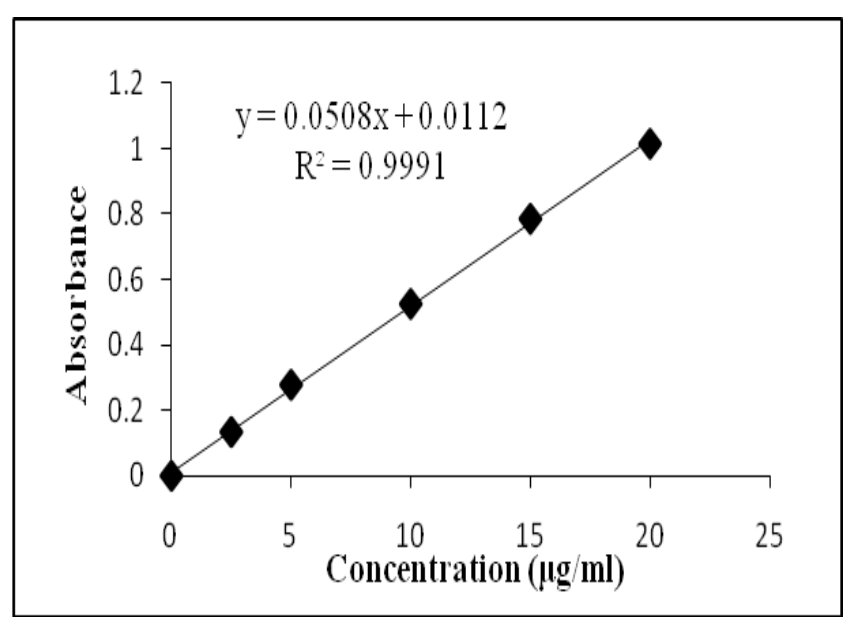

FIG. 2: STANDARD CURVE OF RISPERIDONE

TABLE 2: VALIDATION PARAMETERS

\begin{tabular}{|c|c|c|c|}
\hline Parameters & \multicolumn{3}{|c|}{ Results } \\
\hline Absorption maxima(nm) & \multicolumn{3}{|c|}{202} \\
\hline Linearity range $(\mu \mathrm{g} / \mathrm{ml})$ & \multicolumn{3}{|c|}{ 2.5to 20} \\
\hline $\begin{array}{c}\text { Standard Regression } \\
\text { equation }\end{array}$ & \multicolumn{3}{|c|}{$Y=0.0508 X+0.0112$} \\
\hline Correlation coefficient & \multicolumn{3}{|c|}{0.9991} \\
\hline $\operatorname{LOD}(\mu \mathrm{g} / \mathrm{ml})$ & \multicolumn{3}{|c|}{1.05} \\
\hline $\mathrm{LOQ}(\mu \mathrm{g} / \mathrm{ml})$ & \multicolumn{3}{|c|}{3.34} \\
\hline Stability (hrs) & & 48 & \\
\hline \multirow{2}{*}{ Precision } & Concntration & $\begin{array}{l}\text { Intraday } \\
\text { (\%RSD) }\end{array}$ & $\begin{array}{r}\text { Interday } \\
\text { (\%RSD) }\end{array}$ \\
\hline & $5(\mu \mathrm{g} / \mathrm{ml})$ & 0.385 & 0.313 \\
\hline
\end{tabular}

TABLE 3: RECOVERY STUDY

\begin{tabular}{ccccc}
\hline $\begin{array}{c}\text { Level of } \\
\begin{array}{c}\text { Addition } \\
(\%)\end{array}\end{array}$ & $\begin{array}{c}\text { Formulation } \\
(\mu \mathrm{g} / \mathrm{ml})\end{array}$ & $\begin{array}{c}\text { Addition of } \\
\text { pure drug } \\
(\mu \mathrm{g} / \mathrm{ml})\end{array}$ & $\begin{array}{c}\% \text { Recovery } \\
\text { of pure } \\
\text { drug }\end{array}$ & $\begin{array}{c}\text { Recovery } \\
(\%) \pm S . D .\end{array}$ \\
\hline 80 & 5 & 4 & 100.5 & \\
100 & 5 & 5 & 100.5 & $100.67 \pm 0.29$ \\
120 & 5 & 6 & 101.0 & \\
\hline
\end{tabular}

TABLE 4: DETERMINATIONS OF ACTIVE INGREDIENTS IN TABLETS

\begin{tabular}{cccc}
\hline Sample & $\begin{array}{c}\text { Label } \\
\text { claimed }\end{array}$ & Amount found & $\begin{array}{c}\text { \% Labeled } \\
\text { Claim* }\end{array}$ \\
\hline Risperidone & $2 \mathrm{mg} /$ tablet & $2.01 \pm 0.008$ & 100.5 \\
\hline
\end{tabular}

* Average of three determinations

CONCLUSION: The proposed method was simple, sensitive and reliable with good precision and accuracy. The proposed method is specific while estimating the commercial formulations without interference of excipients and other additives. Hence, this method can be used for the routine determination of Risperidone in pure samples and pharmaceutical formulations.

ACKNOWLEDGEMENTS: The authors are thankful to Orion Laboratories Ltd for providing necessary facilities for conducting this research work.

\section{REFERENCES:}

1. Stahl SM, Essential psychopharmacology. 2nd ed., Cambridge: Cambridge University Press; 2000, 425-434.

2. Titier K, Duridet E, Cardone E, Abouelfath A, Moore N: Simplified high-performance liquid chromatographic method for determination of risperidone and 9hydroxyrisperidone in plasma after overdose. J Chromatogra Bio Sci Appl 2002; 772:373-378.

3. Woestenborghs R, Lorreyne W, Rompaey F, Heykants J: Determination of risperidone and 9-hydroxyrisperidone in plasma, urine and animal tissues by high-performance liquid chromatography. J Chromatogra Bio Sci Appl 1992; 583: 223-230.

4. Titier K, Bouchet S, Pthourcq F, Moore N, Molimard M: High-performance liquid chromatographic method with diode array detection to identify and quantify atypical antipsychotics and haloperidol in plasma after overdose. J Chromatogra Bio Sci Appl 2003; 788:179-185. 
5. Zhou Z, Li X, Li K, Xie Z, Cheng Z, Peng W: Simultaneous determination of clozapine, olanzapine, risperidone and quetiapine in plasma by high-performance liquid chromatography-electrospray ionization mass spectrometry. J Chromatogra Bio Sci Appl 2004; 802:257262.

6. Flarakos J, Luo W, Aman M, Svinarov D, Gerber N, Vouros P: Quantification of risperidone and 9-hydroxyrisperidone in plasma and saliva from adult and pediatric patients by liquid chromatography-mass spectrometry. J Chromatogra A 2004; 1026:175-183.

7. Remmerie BM, Sips L, Vries R, Jong J, Schothuis A, Hooijschuur E. Validated method for the determination of risperidone and 9-hydroxyrisperidone in human plasma by liquid chromatography-tandem mass spectrometry. J Chromatogra Bio Sci Appl 2003; 783:461-472.
8. Moing J, Edouard S, Levron J: Determination of risperidone and 9-hydroxyrisperidone in human plasma by highperformance liquid chromatography with electrochemical detection. J Chromatogra Bio Sci Appl 1993; 614:333-339.

9. Sherif EL, Zeanu B, Houssini M: High performance liquid chromatographic and thin layer densitometric methods for the determination of risperidone in the presence of its degradation products in bulk powder and in tablets. J Pharm Biomed Anal 2005; 36:975-981.

10. Tomar RS, Joseph TJ, Murthy AS, Yadav DV, Subbaiah G, Krishna Reddy KV: Identification and characterization of major degradation products of risperidone in bulk drug and pharmaceutical dosage forms.J Pharm Biomed Anal. 2004; 36:231-235.

11. Validation of Analytical Procedures: Text and Methodology, Proceedings of International Conference on Harmonization (ICH). Geneva, 2005 